УДК 338.24:330

DOI: https://doi.org/10.32689/2618-0065-2020-1(3)-53-65

Денисенко Микола Павлович доктор економічних наук, професор кафедри бізнес-економіки та туризму Київського національного університету технологій та дизайну, м. Київ, вул. Немировича-Данченка, 2, 01011, Україна тел. (044) 256-21-56, e-mail.: profden3@gmail.com

ORCID: 0000-0001-8767-9762

Шапошнікова Олена Миколаївна кандидат наук 3 державного управління, доцент Національного технічного університету «Дніпровська політехніка», проспект Дмитра Яворницького, 19, Дніпро́, Дніпропетровська область, 49000, Україна тел.: (050) 471-20-81, e-mail.: e.shap@i.ua

ORCID: 0000-0001-9146-0069

Будякова Олена Юріївна кандидат економічних наук, старший викладач кафедри бізнес-економіки та туризму, Київського національного університету технологій та дизайну, м. Київ, вул. Немировича-Данченка, 2, 01011, Україна тел.: (044) 256-21-56, e-mail.: bud1971@ukr.net

ORCID: 0000-0001-6028-2650

\title{
ЕКОНОМІЧНІ ЗАХОДИ ДЕРЖАВНОГО УПРАВЛІННЯ ЩОДО ЗАЛУЧЕННЯ ІНВЕСТИЦЙ
}

Анотація. У статті досліджено концептуальні підходи щодо вдосконалення державного управління інвестиційними процесами на регіональному рівні. Акцентована увага на тому, що держава за допомогою заходів економічного регулювання має можливість цілеспрямовано впливати не тільки на формування внутрішніх та залучення зовнішніх інвестицій, а й створення умов для їх спрямування в реальний сектор економіки.

Акцентовано, що інвестиції - це основний інструмент формування мікроекономічних та макроекономічних пропорцій. Поглиблення міжрегіональних диспропорцій у рівнях забезпечення територій інвестиційними ресурсами потребує регіональних особливостей та чинників формування інвестиційного клімату, оцінки існуючих тенденцій, а також здійснення прогнозних передбачень його трансформації.

Наголошено, що покращення інвестиційного клімату в Україні неможливе без ефективного регулювання інвестиційної діяльності в регіонах. Відсутність виваженої регіональної політики призводять до відчутних диспропорцій в економіці держави. У зв'язку з цим ключовою проблемою державної регіональної політики має стати розробка методології аналізування інвестиційної привабливості регіону.

Визначено стратегічне завдання державного управління інвестиційною діяльністю, вирішення якого спрямоване на стабілізацію та прогресивний 
розвиток економіки регіону; реструктуризація його господарського комплексу, створення привабливих умов інвестиційної діяльності.

Обгрунтовано регіональну інвестиційну політику у вигляді циклу, що складається 3 трьох окремих незалежних етапів: концептуальний, етап розробки регіональної інвестиційної політики, етап їі реалізації.

3'ясовано, що для виконання цього завдання доцільно активізувати інвестиційну діяльність, що є пріоритетною умовою стабільного розвитку регіонів, яка здатна залучити фінансові та матеріальні ресурси як вітчизняних, так й іноземних інвесторів, а також раціонально використовувати їх у найбільш пріоритетних галузях економіки.

В роботі обгрунтовано заходи, спрямовані на вдосконалення державного управління інвестиційними процесами на регіональному рівні.

Ключові слова: державне управління, інвестиції, інвестиційний клімат, регіональна політика.

Denisenko Nikolay Pavlovich Doctor of Economics, Professor of the Department of Business Economics and Tourism of Kyiv National University of Technology and Design, Kyiv, ul. Nemirovicha-Danchenko, 2, 01011, Ukraine tel. (044) 256-21-56, email: profden3@gmail.com

ORCID: 0000-0001-8767-9762

Shaposhnikova Olena Nikolaevna Candidate of Sciences in Public Administration, Associate Professor at the National Technical University "Dniprovsk Polytechnic", Dmytro Yavornytskyi Ave., 19, Dnipro, Dnipropetrovsk region, 49000, Ukraine tel.: (050) 471-20-81, email: e.shap@i.ua

ORCID: 0000-0001-9146-0069

Budiakova Olena Yuryevna Candidate of Economics, Senior Lecturer of the Department of Business Economics and Tourism of Kyiv National University of Technology and Design, Kyiv, str. Nemirovicha-Danchenko, 2, 01011, Ukraine tel. (044) 256-21-56, e-mail: bud1971@ukr.net

ORCID: 0000-0001-6028-2650

\section{ECONOMIC EVENTS OF PUBLIC ADMINISTRATION ARE IN RELATION TO BRINGING IN OF INVESTMENTS}

Annotation. The article explores conceptual approaches to improving public administration of investment processes at the regional level. Emphasis is placed on the fact that the state, through economic regulation measures, has the ability to purposefully influence not only the formation of domestic and foreign investment, but also the creation of conditions for their direction in the real sector of the economy. 
It is emphasized that investments are the main instrument of formation of microeconomic and macroeconomic proportions. The deepening of inter-regional disparities in the levels of territorial provision of investment resources requires regional peculiarities and factors of the formation of the investment climate, an assessment of existing trends, and the implementation of predictive predictions of its transformation.

It is emphasized that improvement of the investment climate in Ukraine is impossible without effective regulation of investment activity in the regions. The lack of sound regional policy leads to tangible imbalances in the economy of the state. In connection with this, a key problem of national regional policy should be the development of a methodology for analyzing the investment attractiveness of the region.

The strategic task of the state management of investment activity is determined, the solution of which is aimed at stabilization and progressive development of the regional economy; restructuring of its economic complex, creation of attractive investment conditions.

The regional investment policy in the form of a cycle consisting of three separate independent stages is substantiated: conceptual, the stage of development of regional investment policy, the stage of its implementation.

It has been found that in order to accomplish this task it is advisable to intensify investment activity, which is a priority condition for stable development of the regions, which is able to attract financial and material resources of both domestic and foreign investors, as well as to use them rationally in the most priority sectors of the economy.

The work substantiates measures aimed at improving the state management of investment processes at the regional level.

Key words: public administration, investments, investment climate, regional policy.

Постановка проблеми. В умовах стрімкого розвитку нових технологій інвестиції є найважливішим засобом забезпечення прогресивних структурних зрушень в економіці. Стабілізація та розвиток економіки регіону значною мірою залежать від того, наскільки ефективною $є$ інвестиційна діяльність. У цьому суттєву роль відіграє держава, яка за допомогою методів економічного регулювання має можливість цілеспрямовано впливати не тільки на формування внутрішніх та приплив зовнішніх інвестицій, а й створити умови для їх спрямування в реальний сектор економіки. Розв'язання проблеми інвестування дасть змогу забезпечити прогресивну реструктуризацію на всіх рівнях, перехід до високорозвиненої економіки, тобто до інноваційного розвитку. Стратегічна інвестиційна політика розглядається як найважливіша складова загальної економічної політики, яку проводить держава. Важливим у цьому контексті постають проблеми підвищення конкурентоспроможності 
регіонів в умовах відкритої економіки, здатності центральних та місцевих органів влади до здійснення регіональної інвестиційної політики.

Ефективна державна інвестиційна політика передбачає також використання державних інвестицій як засобу створення первинних умов для залучення приватних та іноземних інвестицій у розвиток пріоритетних галузей економіки. Особлива увага надається інвестиційним проектам зі змішаними інвестиціями - 3 використанням державної частки інвестицій як гарантій цільового спрямування інвестиційних ресурсів.

Основним напрямом підвищення рівня інвестиційного забезпечення повинна стати зміна галузевої структури інвестицій на користь галузей, визнаних пріоритетними в процесі структурної перебудови. В свою чергу держана повинна управляти процесом інвестування у виробництво, тому що саме стан інвестиційної сфери, яка формує чинники виробництва, визначає інтенсивність економічного зростання.

Аналіз останніх досліджень і публікацій. Питанням дослідження особливостей державного управління інвестиційними процесами приділяли увагу українські вчені: Біловодська О.А., Воронкова Т.С., Грищенко I.М., Ілляшенко С.М. Кузьмін О.С., Федоренко В.Г. та ін. Але в науковій літературі не достатньо висвітлено аспекти формування механізмів державного управління інвестиційних процесів на регіональному рівні. Тому стає актуальним розкриття суті інвестиційних процесів в регіонах та механізмів державного управління інвестиційними процесами на регіональному рівні.

Формулювання цілей (мети) статті. Метою статті $€$ визначення особливостей державного управління інвестиційної діяльності на регіональному рівні та обгрунтування економічних заходів щодо залучення інвестицій.

\section{Виклад основного матеріалу дослідження.}

Залучення інвестицій (іноземних та вітчизняних) в економіку України $\epsilon$ життєво важливим засобом усунення інвестиційного «голоду» у країні. Важливо зазначити, що інвестиції $\epsilon$ основою перебудови сектора матеріального виробництва, а тому держава повинна застосовувати весь комплекс економічних, правових та адміністративних заходів для підвищення інвестиційної активності [1].

На сьогоднішній день інвестиції надають суспільству значний стимул для розвитку, породжують систему особливих відносин, людство стає багатшим. Економіка потребує розвитку інвестиційної діяльності, так як для того, хто володіє знаннями в сфері інвестицій, відкриваються нові обрії економічного успіху, виробнича, фінансова, інвестиційна діяльність стають ефективними, а продукт - конкурентоспроможним [2].

Інвестиції - це основний інструмент формування мікроекономічних та макроекономічних пропорцій, що визначає темпи економічного зростання. 
Трансформаційні процеси в економіці України, становлення ринкових структур спричиняють зміну принципів організації й функціонування інвестиційних процесів у регіонах країни. Поглиблення міжрегіональних диспропорцій у рівнях забезпечення територій інвестиційними ресурсами вимагає дослідження регіональних особливостей та чинників створення сприятливого інвестиційного клімату, оцінки існуючих тенденцій та здійснення прогнозних передбачень його трансформації.

Нарощування обсягу інвестицій $є$ необхідною умовою структурної перебудови та економічного зростання як країни, так і регіону. Наявність достатнього обсягу інвестицій у життєво важливі сфери $є$ запорукою ефективного розвитку та підвищення інвестиційної привабливості на різних територіальних рівнях. Оскільки базовою складовою держави є регіони, тому саме стимулюванню нарощування їх інвестиційної привабливості важливо приділяти особливу увагу.

Покращення інвестиційного клімату в Україні неможливо без ефективного регулювання інвестиційної діяльності в регіоні. Відсутність виваженої регіональної політики призведе до значних диспропорцій в економіці країни. У зв'язку 3 цим ключовою проблемою державної регіональної політики має стати розробка методології аналізування інвестиційної привабливості регіону [2].

Створення сприятливого інвестиційного клімату в Україні є одним 3 найважливіших умов залучення інвестицій та подальшого економічного зростання країни [3, с. $55 ; 4]$.

Економічний термін "інвестиційний клімат" дозволяє визначити ту систему орієнтирів, у межах якої відбувається процес інвестування та на основі цього окреслити напрями ефективного використання інвестицій. Він включає стан економіки, соціально-економічну стабільність, рівень розвитку законодавчої бази, інвестиційної інфраструктури та продуктивних сил, валютну й фіскальну політику, стан фінансово-кредитної системи та інвестиційного ринку, інвестиційну активність населення, статус іноземного інвестора та інші фактори.

Як у наукових колах, так і серед підприємців існує багато версій визначення поняття "інвестиційний клімат". Так, переважна більшість економістів трактує інвестиційний клімат як: сукупність соціальних, природних, економічних, політичних або інших передумов, які характеризують доцільність інвестування в ту чи іншу діючу господарчу систему та погоджується 3 тим, що це - комплексне економіко-політичне явище, що формується під впливом значної кількості чинників. Такі фактори, як правило, піддаються адекватній кількісній оцінці, й відтак - i порівняльному аналізу, який дозволяє ідентифікувати рівень інвестиційної привабливості економіки країни або регіону в цілому [2].

Інвестиційний клімат - це узагальнена характеристика сукупності соціальних, економічних, організаційних, правових, політичних, 
соціокультурних передумов, що зумовлює привабливість та доцільність інвестування в ту або іншу господарську систему (економіку країни, регіону, підприємства).

Зауважимо, що по відношенню до територіальних економічних систем поняття "інвестиційний клімат" застосовується поряд 3 категорією "інвестиційна привабливість". Ці поняття подібні, оскільки вони враховують максимальну кількість факторів, що впливають на процес прийняття інвестиційних рішень та подальшу реалізацію інвестиційних проектів.

В свою чергу, інвестиційну привабливість можна визначити як взаємозв'язок інвестиційного потенціалу та інвестиційного ризику (сукупність чинників, під впливом яких складається вірогідність виникнення непередбачених фінансових втрат в умовах невизначеності результатів інвестиційної діяльності або вірогідність повного або часткового недосягнення результатів здійснення інвестицій).

Визначення, угрупування та використання чинників, що впливають на інвестиційний клімат, є важливим й відповідальним процесом, від якого багато в чому залежать управлінські рішення суб'єктів інвестиційного ринку. В цілому під чинником, що впливає на інвестиційний клімат, розуміється процес, явище, дії об'єктивного або суб'єктивного характеру, здатні змінити умови ведення інвестиційної діяльності на певній території.

На інвестиційний клімат регіону можна впливати методами регіонального управління, що являє собою процес цілеспрямованого впливу на об'єкти управління (господарський комплекс регіону, соціальну інфраструктуру, населення й трудові ресурси, природні ресурси та ін.), а також на адміністративно-територіальні одиниці, що перебувають на території регіону.

3 огляду на найважливішу роль інвестицій у функціонуванні й розвитку економічних процесів, особливе значення в регіональному управлінні належить управлінню інвестиційною діяльністю.

Державне управління інвестиційною діяльністю в регіоні в сучасних умовах має найважливіше значення. Розширення економічної самостійності регіонів підсилює роль місцевих органів державної влади й самоврядування в рішенні питань, пов'язаних 3 розвитком інвестиційних процесів, формуванням, перерозподілом та використанням існуючих й потенційно можливих інвестиційних ресурсів, створенням сприятливого інвестиційного клімату для залучення вітчизняних та закордонних інвесторів.

Основна мета управління інвестиційною діяльністю в регіоні - це активізація інвестиційної діяльності й формування сприятливого інвестиційного клімату на території регіону. Для досягнення цієї мети передбачається вирішити ряд завдань стратегічного й тактичного плану.

Стратегічні завдання державного управління інвестиційною діяльністю - це завдання, вирішення яких спрямовано на стабілізацію й прогресивний 
розвиток економіки регіону; реструктуризацію його господарського комплексу; створення привабливих умов інвестиційної діяльності.

До тактичних завдань регіонального управління інвестиційною діяльністю належить розробка заходів та організаційної структури державних органів управління інвестиційною діяльністю в регіоні; сприяння реалізації в регіоні державної інвестиційної політики; розробка на ії основі й реалізація регіональної інвестиційної політики; вибір та обгрунтування пріоритетних об'єктів інвестування; підвищення ефективності інвестиційних процесів; зниження ризиків інвестиційної діяльності.

Об'єктом дослідження інвестиційною діяльністю в регіоні $є$ процес формування й використання інвестиційних ресурсів 3 різних джерел фінансування для комплексного розвитку регіону.

На підставі інвестиційної стратегії в регіоні розроблюється регіональна інвестиційна політика, спрямована на створення сприятливого інвестиційного клімату, залучення вітчизняних та закордонних інвесторів у регіон.

Основними положеннями регіональної інвестиційної політики виступають: цілі учасників регіонального інвестиційного ринку; пріоритети регіональної інвестиційної програми; формування критеріїв відбору регіональних інвестиційних проектів та програм, які будуть підтримуватися адміністрацією регіону при можливості часткового фінансування з бюджету; масштаби інвестиційної програми й можливі реальні джерела пї фінансування; основні елементи регіональної інвестиційної інфраструктури й шляхи їхнього подальшого розвитку; завдання активізації міжнародного інвестиційного співробітництва; місце інвестиційної політики в здійсненні регіональної соціально-економічної політики.

Розробку й практичну реалізацію регіональної інвестиційної політики умовно можна представити у вигляді циклу, що складається 3 трьох окремих незалежних етапів [2].

1. Концептуальний етап - формування концепції регіональної інвестиційної політики, аналізування регіонального потенціалу й регіональних інвестиційних ризиків, інвестиційної ємності регіонального ринку.

2. Етап розробки регіональної інвестиційної політики - розробка регіональної інвестиційної програми й системи заходів їі що забезпечують, створення виконавчих органів програми й інфраструктури.

3. Етап реалізації регіональної інвестиційної політики - практичне здійснення заходів регіональної інвестиційної політики, контроль та аналіз їхнього виконання, оперативне внесення коригувальних змін та впливів, професійний супровід процесу реалізації регіональної інвестиційної політики.

У зв'язку з тим, що ефективне управління інвестиційною діяльністю в промисловому регіоні $є$ найважливішим чинником, що створює привабливі 
умови для інвестування в господарську систему, у сучасних умовах великого значення набуває його вдосконалювання 3 метою активізації інвестиційної діяльності, стимулювання припливу інвестиційних вкладень в економіку.

Проблема підвищення інвестиційної привабливості регіонів України займає важливе місце серед інших досліджуваних у науковій періодиці регіональних проблем.

Дослідження проблем інвестування економіки завжди перебувало в центрі уваги економічної науки. Це обумовлено тим, що інвестиції зачіпають глибинні основи господарської діяльності, визначаючи процес економічного зростання в цілому. У сучасних умовах вони виступають найважливішим засобом забезпечення умов виходу зі сформованої економічної кризи, структурних зрушень у національному господарстві, забезпечення технічного прогресу, підвищення якісних показників господарської діяльності на мікроі макрорівнях.

Нарощування обсягу інвестицій $\epsilon$ необхідною умовою структурної перебудови й економічного зростання країни та регіону. Наявність достатнього обсягу інвестицій у життєво важливі сфери $є$ запорукою ефективного розвитку та підвищення інвестиційної привабливості на різних територіальних рівнях. Оскільки базовою складовою держави є регіони, тому саме стимулюванню нарощування їх інвестиційної привабливості доцільно приділяти особливу увагу.

Для виходу із кризової ситуації, як політичної, так й економічної, залучення інвестицій до внутрішнього ринку є складним та ризикованим напрямом діяльності. Особливу увагу доцільно наділяти державним проектам 3 інвестуванням в промисловість та виробництво товарів народного споживання, які мають найбільше значення для національної економіки, зменшити на національному ринку кількість імпортованих товарів [1].

Набувають все більшого значення питання залучення іноземних інвестицій в українську економіку оскільки держава не має достатніх внутрішніх фінансових ресурсів для вирішення багатьох проблем соціального та економічного характеру. Іноземні інвестиції - важлива складова структури інвестиційного ресурсу України. Іноземне інвестування, як невід'ємний атрибут сучасних світогосподарських зв'язків, - явище багатогранне й динамічне [5, с. 70].

Іноземні інвестиції дають можливість виготовлення конкурентоспроможної продукції без нарощування боргових зобов'язань, активізують модернізацію технологічних процесів, сприяють розвитку малого та середнього підприємництва, яке спеціалізується на обслуговуванні великого бізнесу. Світовий дослід свідчить, що найкоротшим шляхом піднесення на якісно новий рівень розвитку продуктивних сил країни $\epsilon$ оптимальне використання інвестицій у різноманітних організаційноправових формах. 
Активізація інвестиційної діяльності $€$ пріоритетною умовою стабільного розвитку регіонів, яка здатна залучити фінансові та матеріальні ресурси як вітчизняних, так й зарубіжних інвесторів, а також раціонально їх використовувати в найбільш пріоритетних галузях економіки. Обсяг залучених в економіку регіону інвестицій - один із критеріїв ефективності його функціонування.

На даний час Україна вимагає значних обсягів інвестицій, необхідно: використовувати потенціал території, який включає наявність високого природно-ресурсного потенціалу, високий середній рівень кваліфікації робітників, високорозвинену промисловість, сприятливе географічне розташування; провести реструктуризацію та оптимізацію неефективних виробництв у регіоні; сприяти розвитку підприємств малого та середнього бізнесу шляхом використання міжнародних програм; збільшити інформованість учасників інвестиційного процесу 3 питань адміністративних дій та нормативно-правової бази, яка необхідна для здійснення інвестицій; сприяти формуванню та розвитку інноваційної діяльності, що забезпечить сталий науково-технічний прогрес та створення конкурентоспроможного виробництва. Це, в свою чергу, сприятиме прискореному технологічному переоснащенню промислового виробництва.

Покращення інвестиційної привабливості регіону за запропонованими напрямами дає змогу залучити у майбутньому значно більшу кількість інвесторів.

Безумовно, підтримка економічного розвитку регіону має супроводжуватися структурною перебудовою виробництва з обов'язковим дотриманням принципів сталості. Зокрема, важливими аспектами розвитку $€$ : рішення соціально-економічних та екологічних проблем, прискорення розвитку людського капіталу [6, с. 15], впровадження інновацій, стимулювання організації високотехнологічних виробництв тощо. Для виконання цих завдань слідувало б орієнтувати регіональну інвестиційну політику на вибіркове стимулювання інвестиційної діяльності згідно 3 обраними пріоритетами, а також на створення привабливого інвестиційного клімату з урахуванням основних регіональних переваг.

Як свідчить світовий досвід, визначення національних пріоритетних напрямів розвитку науки i нових технологій складається 3 трьох взаємозалежних процесів: формування головної стратегічної мети держави, облік загальновизнаних світових пріоритетів та відображення національних особливостей, специфіки країни. Урахування досвіду розвинених країн у той час, коли Україна перебуває на шляху пошуку підходів та інструментів, що змогли б забезпечити стійкий економічний розвиток, має надзвичайно велике значення. Згідно з вимогами часу основою стратегічного курсу розвитку України, їі визначальними пріоритетами мають стати розробка й реалізація державної політики, спрямованої на структурну модернізацію господарського комплексу, якнайшвидший його перехід на інноваційний 
шлях розвитку і становлення України як високотехнологічної держави. Пріоритет інноваційного розвитку національної економіки й активна роль держави у процесі структурних перетворень визначено на найвищому державному рівні. Інноваційний розвиток наразі стає не лише «національною економічною ідеєю», а й тактикою державної економічної й гуманітарної політики. Розробка системи державного регулювання включає також визначення найважливіших соціальних, економічних та інших цілей і завдань на перспективу, в т.ч. соціальних орієнтирів, основних пропорцій i структурних зрушень, а також найбільш ефективної соціально-економічної політики, яка сприяє їхній реалізації [7, с. 34].

Для вирішення визначених завдань та досягнення поставленої мети доцільна розробка Концепції та реалізація дій за наступними напрямами (табл. 1).

Таблиця 1

\section{Напрями реалізації концепції}

\begin{tabular}{|c|c|}
\hline & $\mathbf{X a}$ \\
\hline $\begin{array}{l}\text { Формування } \\
\text { сприятливого } \\
\text { інвестиційног } \\
\text { о клімату та } \\
\text { позитивного } \\
\text { іміджу } \\
\text { регіону }\end{array}$ & $\begin{array}{l}\text { - створення Агентства із залучення інвестицій для здійснення комплексної } \\
\text { підтримки інвестиційних проектів та забезпечення взаємодії між інвесторами і } \\
\text { органами влади; } \\
\text { - оптимізацію процедур одержання дозвільних документів, створення «єдиного } \\
\text { інвестиційного вікна»; } \\
\text { - забезпечення ефективності та прозорості функціонування механізмів державно- } \\
\text { приватного партнерства; } \\
\text { - розширення співпраці з міжнародними організаціями, у тому числі фінансовими, } \\
\text { забезпечення інформаційної й організаційної підтримки іноземним інвесторам; } \\
\text { - розвиток міжрегіонального та транскордонного співробітництва; } \\
\text { - здійснення рекламно-інформаційної підтримки внутрішнього ринку, } \\
\text { рекламування природно-ресурсного та економічного потенціалу територій, } \\
\text { розробку й поширення презентаційних матеріалів серед інвестиційної спільноти; } \\
\text { - активізація виставкової діяльності, проведення економічних, інвестиційних } \\
\text { форумів, конференцій, семінарів. }\end{array}$ \\
\hline $\begin{array}{l}\text { Утворення } \\
\text { необхідних } \\
\text { передумов } \\
\text { для } \\
\text { структурно- } \\
\text { інноваційної } \\
\text { перебудови } \\
\text { економіки } \\
\text { регіону }\end{array}$ & $\begin{array}{l}\text { - розробка Програми інноваційно-інвестиційного розвитку регіону; } \\
\text { - створення бази інвестиційних пропозицій та надання підтримки проектам, } \\
\text { спрямованим на розвиток високотехнологічної конкурентоспроможної продукції, } \\
\text { розвиток інфраструктурних та базових секторів економіки регіону, об'єктів } \\
\text { альтернативної енергетики; } \\
\text { - включення до галузевих програм інвестиційних проектів, спрямованих на випуск } \\
\text { високотехнологічної продукції, підвищення ефективності використання } \\
\text { енергоресурсів та мінеральної сировини; } \\
\text { - проведення конкурсів на краще технологічне рішення виробничих та } \\
\text { екологічних проблем; } \\
\text { - розбудова інноваційної інфраструктури, організація підготовки фахівців } 3 \\
\text { венчурного підприємництва. }\end{array}$ \\
\hline $\begin{array}{l}\text { Забезпеченн } \\
\text { інвестиційн } \\
\text { о розвитку } \\
\text { територій } \\
\text { регіону }\end{array}$ & $\begin{array}{l}\text { - впровадження програмно-цільового планування та збалансування розвитку } \\
\text { територій регіону відповідно до їх інвестиційних можливостей; } \\
\text { - розвиток інформаційних баз інвестиційних пропозицій та об'єктів потенційного } \\
\text { інвестування, створення «інвестиційної карти» регіону; } \\
\text { - сприяння функціонуванню в регіоні передбачених законодавством спеціальних } \\
\text { режимів інвестиційної діяльності; } \\
\text { - стимулювання створення територій компактного розміщення бізнесу - кластерів }\end{array}$ \\
\hline
\end{tabular}




\begin{tabular}{|c|c|}
\hline & $\begin{array}{l}\text { озвиненою інфраструктурою; } \\
\text { підвищення кваліфікації управлінських кадрів } 3 \text { питань залучення інвестицій та } \\
\text { зробки інвестиційних проектів розвитку територій. }\end{array}$ \\
\hline $\begin{array}{l}\text { Ia } \\
\text { Ba } \\
\text { Bx } \\
\text { B }\end{array}$ & $\begin{array}{l}\text { - надання пріоритетного статусу інвестиційним проектам, спрямованим на } \\
\text { розвиток інфраструктурних та екологічних виробництв, об'єктам альтернативної } \\
\text { енергетики; } \\
\text { - впровадження методики оцінки ефективності інвестиційного розвитку з позицій } \\
\text { реалізації стратегічних завдань розвитку регіону; } \\
\text { - сприяння розробці та реалізації інфраструктурних та соціальних проектів } \\
\text { регіонального й локального масштабу (транспорт, ЖКГ тощо), забезпечення їх } \\
\text { фінансування з державного та місцевого бюджетів пошук донорів й приватних } \\
\text { інвесторів. }\end{array}$ \\
\hline $\begin{array}{l}\text { Мо } \\
\text { рес } \\
\text { заб } \\
\text { інв } \\
\text { про } \\
\text { рег }\end{array}$ & $\begin{array}{l}\text { - формування регіонального ринку інвестиційних ресурсів шляхом залучення } \\
\text { заощаджень населення, коштів фінансових посередників, ресурсів банківської } \\
\text { системи та бюджетних коштів; } \\
\text { - сприяння становленню та розвитку індустрії прямого інвестування та венчурного } \\
\text { капіталу; } \\
\text { - залучення коштів міжнародних фінансових організацій, іноземних кредитів; } \\
\text { - створення системи гарантування та страхування інвестиційних вкладень в } \\
\text { пріоритетні напрями інвестиційного розвитку регіону. }\end{array}$ \\
\hline
\end{tabular}

3 метою створення оптимальних умов активізації інвестиційної діяльності має бути врахована специфіка регіонів України та ресурсів, що знаходяться на цих територіях. Для підвищення інвестиційної привабливості регіону, конкурентоспроможності підприємств та розвитку території, доцільна розробка відповідного комплексу заходів та створення сприятливих умов для його виконання. Разом 3 тим, для досягнення цього ефекту слідувало б виявити внутрішні чинники, що впливають на інвестиційну привабливість регіону, а також встановлювати вплив цих факторів, забезпечити прискорений соціально-економічний розвиток регіону та пріоритетних галузей виробництва.

\section{Висновки і перспективи подальших досліджень.}

3 метою вдосконалення державного управління інвестиційними процесами на регіональному рівні доцільно:

1. Використовувати потенціал території, який включає наявність високого природно-ресурсного потенціалу, високорозвинену промисловість, сприятливе географічне розташування;

2. Провести реструктуризацію та оптимізацію неефективних виробництв у регіоні;

3. Сприяти розвитку підприємств малого і середнього бізнесу шляхом використання міжнародних програм та фінансуванням перспективних проектів;

4. Збільшити інформованість учасників інвестиційного процесу 3 питань адміністративних дій та нормативно-правової бази, яка необхідна для здійснення інвестицій; 
5. Сприяти формуванню та розвитку інноваційної діяльності, що забезпечить сталий науково-технічний прогрес та створення конкурентоспроможного виробництва.

Це, в свою чергу, сприятиме підвищенню інвестиційної привабливості регіонів України та зростанню обсягів інвестиційних надходжень.

\section{Jimepamypa:}

1. Шапошнікова О.М. До питання регулювання інвестиційного процесу в промисловості України / О.М. Шапошнікова // Dinamika naukowych badań - 2007: materiały Miẹdzynarodowej konferencji. - Przemyśl. Nauka I studia. - T. 1. -Ekonomiczne nauki (15-31 lipca 2007 r.). - S. 35-37.

2. Шапошнікова О.М. Особливості залучення іноземних інвестицій в економіку України / O.M. Шапошнікова // Perspektywiczne opracowania nauki I techniki - 2007: materiały II Miẹdzynarodowej naukowi-praktycznej konferencji . - Przemyśl. Nauka I studia. T. 1. - Ekonomiczne nauki (16-30 listopada 2007 r.). - S. 61-66.

3. Mykola Denysenko, Alona Melnyk, Zorina Shatskaya, Olena Budiakova International regulatory experience business activity // M. Denysenko, A. Melnyk, Z. Shatskaya, O. Budiakova. - Research and Innovation: Collection of scientific articles. - Yunona Publishing, New York, USA. - 2019. - 200 p. - p. 55-58. - Режим доступу: http://conferencii.com/files/archive/2019-02.pdf

4. Стан та тенденції розвитку сучасного підприємництва: монографія / за ред. д.е.н., проф. М.П. Денисенка. - К.: ТОВ «ДКС центр», 2019. - 464 с.

5. Денисенко М.П. Іноземне інвестування економіки України / М. П. Денисенко // Актуальні проблеми економіки. - 2016. - №7, С.70-77.

6. Денисенко М. П., Будякова О. Ю. Підвищення індексу людського капіталу важлива складова інноваційної кадрової політики підприємств. Економіка та держава. 2019. № 4. C. 11-17. DOI: 10.32702/2306-6806.2019.4.11

7. Денисенко М.П. Механізм державного управління інноваційної діяльності на регіональному рівні / М.П. Денисенко, О.Ю. Будякова // Науковий вісник: Державне управління. - № 1. - 2018. - С. 34-47.

\section{References:}

1. Shaposhnikova, O. (2007). K pytanniu rehuliuvannia investytsijnoho protsesu v promyslovosti Ukrainy [On the regulation of the investment process in the industry of Ukraine]. Proceedings from: Mizhnarodna konferentsiia «Dinamics scientific research»: Industry. Science and studies. T. 1. Economical sciences». (pp. 35-37). Premysl: [in Poland].

2. Shaposhnikova, O. (2007). Osoblyvosti zaluchennia inozemnykh investytsij v ekonomiku Ukrainy [Features of attraction of foreign investments in the economy of Ukraine]. Proceedings from: II Mizhnarodna naukovo-praktychna konferentsiia «Perspective development of science and technology»: Industry. Science and studies. T. 1. Economical sciences». (pp. 6166). Premysl: [in Poland].

3. Denysenko, M., Melnyk, A., Shatskaya, Z., Budiakova, O. (2019). "International regulatory experience business activity”. Doslidzhennia ta innovatsii, p. 55-58.

4. Denisenko, M.P (2019). Stan ta tendentsii rozvytku suchasnoho pidpryiemnytstva [The current trends and trends of modern entrepreneurship], DKS tsentr. Kyiv: [in Ukrainian].

5. Denisenko, M.P (2016). Inozemne investuvannia ekonomiky Ukrainy [Foreign investment of the economy of Ukraine]. Aktual'ni problemy ekonomiky - Current problems of the economy, 7, 70-77 [in Ukrainian]. 
6. Denisenko, M.P \& Budiakova, O. Yu. (2019). Pidvyschennia indeksu liuds'koho kapitalu - vazhlyva skladova innovatsijnoi kadrovoi polityky pidpryiemstv[Enhancing human capital index - important complex of innovative personnel policy]. Ekonomika ta derzhava Economy and the state, 4, 11-17 [in Ukrainian]. DOI: 10.32702/2306-6806.2019.4.11

7. Denisenko, M.P \& Budiakova, O. Yu. (2018). Mekhanizm derzhavnoho upravlinnia innovatsijnoi diial'nosti na rehional'nomu rivni [The mechanism of state management of innovation activity at the regional level] Naukovyj visnyk: derzhavne upravlinnia - Scientific Bulletin: State management, 1, 34-47 [in Ukrainian]. 